ficial for U.S. courts not to have to deal with cases that include many foreign elements and political implications. Nor need one worry that such trends will drain the docket of federal and state courts. They are not exactly short of business.

If the objective is to increase the conditions for trade and direct foreign investment between the United States and the Soviet Union, a stable legal environment is unquestionably an important factor. It is worth remembering that it can be supplied in many ways. There is no special virtue in forcing the Soviet Union to litigate in U.S. courts, any more than there is a special virtue in forcing United States nationals to litigate in Soviet courts. Of importance is the creation of a stable rule of law. Like due process, the rule of law is not the exclusive attribute of one type of institution but is a set of procedures that can be demanded and replicated in diverse institutional arrangements, some of which provide comparatively higher returns in terms of fairness and economy. The resolution of commercial disputes between U.S. nationals and the Soviet Government can be accomplished at the institutional international level more efficiently than by private arbitration or by two parallel national judicial processes.

W. MichaEl REISMAN

\title{
HARNESSING INTERNATIONAL LAW TO RESTRAIN AND RECAPTURE INDIGENOUS SPOLIATIONS
}

The ritual of condemnation of foreign corporations' spoliations of the resources of developing countries and their elevation to the level of international concern have obscured the problem of spoliations by national officials of the wealth of the states of which they are temporary custodians. The pathology is not restricted to developing countries. Quite the contrary. Gibbon called it "the most infallible symptom of constitutional liberty." But the consequences for developing countries are often catastrophic, for the issue is not garden-variety corruption. The amounts involved can be stunning, at times reportedly equaling the national debt. ${ }^{1}$ In some cases, absconding officials have left the economies of their countries ransacked and destroyed.

Factually, the problem of indigenous spoliation is international in terms of means and consequences. In terms of means, the misappropriated funds cross international boundaries to find a haven. In terms of consequences, a

\footnotetext{
' For background, see D. Delamaide, Debt Shock: The Full Story ol the World CREDIT Crisis (1984); Henry, Where the Money Went, New Republic, Apr. 1 4,1986 , at 20; LDC Capital Flight, WORLD FIN. MARKETS, March 1986, at 13-15; LDC Debl: Debt Relief or Market Solutions?, id., September 1986, at 1, 6-7. See also Camdessus, IWF.Chef Camdessus: Wir müssen alle Mittel mobilisieren, Die Welt, Sept. 15, 1988, at 13, cols. 1-6.
} 
significant part of the burden of reconstruction of the spoliated economies is perforce shifted to the international community where it is folded into development assistance. Its pathogeny is conveniently forgotten.

Legally, the problem is international, owing to changes in basic conceptions and principles of contemporary international law. Spoliation is not a legal problem if the supreme leader can plausibly say "l'état, c'est moi." As long as the proprietary state was legitimate, there could be no question that the sovereign or his family was entitled to alienate or liquidate parts of the natural heritage of his fief and cache it in a convenient financial center elsewhere in the world. ${ }^{2}$ But the incorporation of democratic ideals into international law and into transnational notions of political legitimacy, which has found its most authoritative expression in the United Nations Charter, changes, by necessary implication, the competence of national officials to dispose of the assets of a nation-state.

The point of a declaration about the permanent sovereignty of peoples over their natural resources ${ }^{3}$ is not that the resources in question may not be mined and sold. Such a doctrine would render them valueless. The point is rather that the national community in which the resources are found is to be a significant beneficiary of their exploitation. By implication here, and explicitly in other international instruments, the nation-state is now expected to contribute to the welfare of all inhabitants, without even having the right to discriminate among them. ${ }^{4}$

As in many other areas of international law, innovative constitutive principles such as these coexist uneasily with persisting structural features of the classical state system: deference to the finality of a government's acts accomplished within national territory, sovereign immunity in foreign judicial instances, and so on. Indeed, the autonomy of national jurisdiction and the right of states to choose their own form of economic organization have been invoked in defense of states whose bank secrecy laws have shielded spoliations. Some of these states insist that bank secrecy laws, rather than shielding the guilty, generally benefit persecuted peoples whose wealth is targeted for expropriation by vicious governments. Even when spoliations that all would condemn are taking place, the continuing crisis and competition of the international political system inevitably press other states to adjust the application of high principles to current exigencies. The locus classicus is

${ }^{2}$ But cf. E. DE VATTEL, THE LAW OF NATIONS, bk. I, ch. II, $\$ 15 ;$ see also id., ch. IV, $\S \S 39,49$ (Carnegie trans. 1916) (1758).

${ }^{3}$ Resolution on Permanent Sovereignty over Natural Resources, GA Res. 1803, 17 UN GAOR Supp. (No. 17) at 15, UN Doc. A/5217 (1962).

${ }^{4}$ On the welfare function of contemporary international law, see Friedmann, Human Welfare and International Lau-A Reordering of Priorities, in TRANSNATIONAL LAW IN A Changing Sociery 113 (1972). Wilfred Jenks, in THE COMMON LAW OF MANKIND (1958), wrote eloquently on this subject. Jenks described international law as "increasingly shifting from the formal structure of the relationships between States and the delimitation of their jurisdiction to the development of substantive rules on matters of common concern vital to the growth of an international community and to the individual well-being of the citizens of its member States." Id. at 17.

For examples of specific relevant international instruments, see infra note 5. 
Franklin D. Roosevelt's cryptic comment on Anastasio Somoza: "He may be an S.O.B., but he's our S.O.B."

One of the anomalies of these cross-currents has been confusion and paralysis about the status of national funds spoliated by high government officials and cached abroad. The agents of these spoliations may themselves be nationals of the violated collectivity, but that no more makes their acts exclusively matters of domestic jurisdiction than would any other violation of human rights. Such spoliations are violations of the internationally guaranteed rights of peoples to use their national wealth for naticnal welfare. Because the spoliations cannot be accomplished without havens abroad, the exercise of the banking jurisdiction of another state in such a way as to conceal funds is effectively part of the delict. It violates the international legal rights of the deprived states and may itself constitute an international legal wrong.

Because the legal principles have remained obscure, the international unlawfulness of making possible and aiding spoliations by harboring them has not been specified. National efforts to regain funds have perforce been undertaken on a case-by-case basis. But since the governments needing to regain their funds most urgently have often been spoliated to the point where their institutions are close to bankruptcy, each has lacked the institutional infrastructure and the funds necessary for this task. As a consequence, there are many such ad hoc programs now under way, but there is no accumulation of readily sharable international experience. In a number of instances, national attorneys have made themselves available on a pro bono basis, but such efforts have lacked the authority of an international mandate. In the meantime, the expelled national officials, who have followed their funds into relatively safe jurisdictions, are able to use those funds to purchase skilled legal services to preserve their gains.

Has not the time come for the international community to address this issue directly? It is proposed that, as a first step, an international declaration be drafted (1) characterizing, unequivocally, spoliations by national officials as a breach of national trust and of international law; (2) imposing on other governments an obligation of supplying information and cooperation; and (3) characterizing the failure of other governments to prevent such funds from being cached in their jurisdiction and to aid in their recapture as complicity, after the fact, and, as itself, an international delict. The authority of such an endeavor may be rested on the Resolution on Permanent Sovereignty, on the United Nations Charter, on various human rights declarations and, in particular, on Article 19 of the Universal Declaration of Human Rights regarding freedom of information. ${ }^{5}$

As a second step, the United Nations should consider forming an international high commission for the retrieval of diverted national wealth. The

\footnotetext{
${ }^{5}$ Other relevant human rights instruments include the International Covenant on Economic, Social and Cultural Rights, GA Res. 2200, 21 UN GAOR Supp. (No. 16) at 49, UN Doc. A/6316 (1966), especially Art. 1(2); the International Covenant on Civil and Political Rights, GA Res. 2200, 21 UN GAOR Supp. (No. 16) at 52, UN Doc. A/6316 (1966), especially Art. 1(2):
} 
commission would be charged with responding to the requests of member governments to identify the location of purloined funds and to secure their return by negotiation or, where appropriate, by judicial action. The statute of the agency would grant it international legal personality and authorize it to cover its reasonable expenses from the funds regained.

The cultivation of responsibility and fidelity to duty in public officials is not a problem unique to developing countries. Developed countries with relatively stable governments are also plagued by official corruption; indeed, in absolute numbers, this corruption may exceed that of poorer states. ${ }^{6}$ But its scale and consequences for economies of poorer states have reached the point where it can no longer be ignored. Unless some international mechanisms are set in place to facilitate economic recapturing of the funds and, in the future, to deter indigenous spoliations, urgent welfare goals of the international legal system will remain unfulfilled.

W. MICHAEL REISMAN*

All peoples may, for their own ends, freely dispose of their natural wealth and resources without prejudice to any obligations arising out of international economic co-operation, based upon the principle of mutual benefit, and international law. In no case may a people be deprived of its oum means of subsistence [emphasis supplied].

In addition, the European Convention for the Protection of Human Rights and Fundamental Freedoms, Nov. 4, 1950, 213 UNTS 221, especially Art. 9 regarding freedom of information; the Final Act of the [Helsinki] Conference on Security and Co-operation in Europe, Aug. 1, 1975, 73 DEP'T ST. Bull. 323 (1975), especially pt. VII, "Respect for Human Rights and Fundamental Freedoms," and pt. VIII, "Equal Rights and Self-Determination of Peoples"; the American Declaration of the Rights and Duties of Man (1948), Res. XXX, 6 NINTH INTERNA. TIONAL ConfERENCE of AMERican STATES, Actas y Documentos 297 (1953), especially Art. IV regarding freedom of investigation, opinion, expression and dissemination of ideas; the American Convention on Human Rights, Nov. 22, 1969, reprinted in ORGANIZATION OF american States, Handbook of Existing Rules Pertaining to Human Rights in the INTER-AMERICAN SYSTEM, OEA/Ser.L/V/II.65, doc. 6, at 103 (1985), especially Art. I3, "Freedom of Thought and Expression," and Art. 21, "Right to Property." These texts are also reproduced in I. BROWNLIE, BASIC DOCUMENTS ON HUMAN RighTS (1981).

6 See generally W. M. ReISMAN, Folded LIEs (1979); J. NoonAN, BRIBEs (1984).

* The author acknowledges the useful comments of Mahnoush $\mathrm{H}$. Arsanjani and preliminary discussions with Frank Penna, Kevin Boyle and Katarina Tomsevski. 